In addition to members of the editorial board, we sought reviews from a number of other scholars. We wish to acknowledge our appreciation to all those who returned reviews during 1993.

\begin{tabular}{ll} 
J. Lawrence Aber & Peter Fonagy \\
Mark Aber & Uta Frith \\
Adrian Angold & \\
Robert Asarnow & Jody Ganiban \\
Steve Asher & Cynthia Garcia-Coll \\
Catherine Ayoub & Per Gjerde \\
& Susan Goldberg \\
Douglas Barnett & Irving Gottesman \\
Jack Bates & \\
Leila Beckwith & Constance Hammen \\
Marjorie Beeghly & Susan Harter \\
Jay Belsky & Cindy Hazan \\
Karen Bierman & Steven Hinshaw \\
Sidney Blatt & Peter Hobson \\
Inge Bretherton & Grayson Holmbeck \\
Jeanne Brooks-Gunn & Jill Hooley \\
William Bukowski & Hyman Hops \\
& \\
Greg Carey & Nick Ialongo \\
Heather Carmichael-Olsen & Carroll Izard \\
Robbie Case & \\
Avshalom Caspi & Deborah Jacobvitz \\
Jude Cassidy & \\
Robert Clyman & Denise Kandel \\
Douglas Coatsworth & Joan Kaufman \\
Jeff Cohn & Phil Kendall \\
Wendy Coster & Rafael Klorman \\
Emory Cowen & R. Roger Kobak \\
James Coyne & Grazyna Kochanska \\
Keith Crnic & \\
Mark Cummings & Peter Lafreniere \\
Thomas Dishion & Michael Lamb \\
Geraldine Downey & Barbara Landau \\
Mary Dozier & Alan Leslie \\
Jean Dumas & Alicia Lieberman \\
Ann Easterbrooks & Jeff Lockman \\
Craig Edelbrock & Katherine Loveland \\
& Suniya Luthar \\
Lynn Feagans & Michael Lynch \\
Kurt Fischer & Karlen Lyons-Ruth \\
\hline
\end{tabular}


Carol Malatesta-Magai

Elizabeth McCauley

Robert McMahon

Andrew Meltzoff

Terrie Moffit

Marlene Moretti

Gil Noam

Susan Nolan-Hoeksema

Robert Noll

Ross Parke

Jeffrey Parker

Jane Pearson

Greg Pettit

Robert Pianta

Alice Pope

Joseph Price

Frank Putnam

David Quinton

Richard Rende

John Richters

John Reiser

Carol Rodning

Sally Rogers

Barbara Rogoff

Susan Rose

Ken Rubin
Ron Seifer

Ted Shapiro

Martha Shenton

Roberta Simmons

Arietta Slade

Judith Smetana

Linda Smith

James Snyder

Judith Solomon

Susan Spieker

Matt Speltz

Margaret Spencer

Magda Stouthamer-Loeber

Doug Teti

Ross Thompson

Sheree Toth

Ed Tronick

Bahr Weiss

John Weisz

Jennifer White

Robert Wozniak

Fred Volkmar

Brenda Volling

Alastair Younger

Charles Zeanah

Robert Zucker 


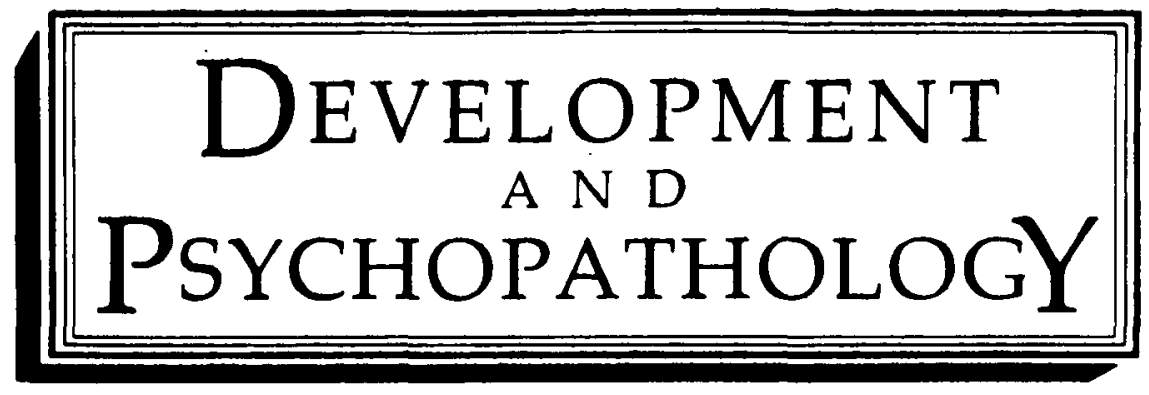

Volume 5, 1993

Editor: Dante Cicchetti

Deputy Editor: Barry Nurcombe 


\section{Contents to Volume 5}

Volume 5

WINTER/SPRING

Numbers 1/2

1993

\section{CONTENTS}

Special Issue: Toward a Developmental Perspective on Conduct Disorder

JOHN E. RICHTERS

AND DANTE CICCHETTI

JOHN E. RICHTERS AND DANTE CICCHETTI

STEPHEN P. Hinshaw, BENJAMIN B. LAHEY, AND ELIZABETH L. HART

Thomas M. ACHENBACH

MARK ZOCCOLILLO

CAROLYn ZAHN-WAXLeR

E. JANe Costello AND ADRIAN ANGOLD

Rolf Loeber, Phen Wung, Kate Keenan, Bruce Giroux, Magda Stouthamer-Loeber, WeLMOET B. VAN KAMMEN, AND BARBARA MAUGHAN
1 Editorial. Toward a developmental perspective on conduct disorder

Articles

$5 \quad$ Mark Twain meets DSM-III-R: Conduct disorder, development, and the concept of harmful dysfunction

31 Issues of taxonomy and comorbidity in the development of conduct disorder

51 Taxonomy and comorbidity of conduct problems: Evidence from empirically based approaches

65 Gender and the development of conduct disorder

79 Warriors and worriers: Gender and psychopathology

91 Toward a developmental epidemiology of the disruptive behavior disorders

103 Developmental pathways in disruptive child behavior 
Terrie E. Moffitt

Bruce F. Pennington AND LOISA BENNETTO

Herbert C. Quay

Elizabeth J. SUSMAN

MARK T. GREenBERG, MATTHEW L. SPELTZ, AND MiCHELlE DEKLyEN

EVERETT WATERS, German POSADA, JUDITH CROWELL, AND KENG-LING LAY

DAVID P. FARRINGTON

JOHN B. REID

JOHN D. COIE AND MARLENE R. JACOBS

Alan E. Kazdin

Kenneth A. Dodge

JOAN MCCORD

DANTE CicchetTI AND JOHN E. RICHTERS
135 The neuropsychology of conduct disorder

153 Main effects or transactions in the neuropsychology of conduct disorder? Commentary on "The neuropsychology of conduct disorder"

165 The psychobiology of undersocialized aggressive conduct disorder: A theoretical perspective

181 Psychological, contextual, and psychobiological interactions: A developmental perspective on conduct disorder

191 The role of attachment in the early development of disruptive behavior problems

215 Is attachment theory ready to contribute to our understanding of disruptive behavior problems?

225 Motivations for conduct disorder and delinquency

243 Prevention of conduct disorder before and after school entry: Relating interventions to developmental findings

263 The role of social context in the prevention of conduct disorder

277 Treatment of conduct disorder: Progress and directions in psychotherapy research

311 The future of research on the treatment of conduct disorder

321 Conduct disorder and antisocial behavior: Some thoughts about processes

331 Developmental considerations in the investigation of conduct disorder 
Volume 5

Summer 1993

Number 3

\section{CONTENTS}

Peter Szatmari, Saroj Saigal, Peter Rosenbaum, AND Dugal CAMPBELl

Byron Egeland, Robert Pianta, AND MAureen A. O'Brien

LISBETH ALPERN AND KARLEN LYONS-RUTH

M. ANN EASTERBROOKS, CHERILYN E. DAVIDSON, AND RaChel ChazaN

CONNIE KASARI, MARIAN SIGMAN, AND NURIT YIRMIYA

Kiran Amin, Virginia I. Douglas, MORTON J. MENDELSON, AND JOAN DUFRESNE

Nick Ialongo, Gail Edelsohn, LISA WERTHAMER-LARSSON, LISA CROCKETT, AND SHEPPARD KELLAM

BRENDA L. VOLLING, Carol MacKinnon.Lewis, DAVID RABINER, AND LAILA P. BARADARAN

JILL RIERDAN AND ELISSA KOFF
345 Psychopathology and adaptive functioning among extremely low birthweight children at eight years of age

Maternal intrusiveness in infancy and child maladaptation in early school years

371 Preschool children at social risk: Chronicity and timing of maternal depressive symptoms and child behavior problems at school and at home

389 Psychosocial risk, attachment, and behavior problems among school-aged children

403 Focused and social attention of autistic children in interactions with familiar and unfamiliar adults: A comparison of autistic, mentally retarded, and normal children

415 Separable/integral classification by hyperactive and normal children

433 Are self-reported depressive symptoms in first-grade children developmentally transient phenomena? A further look

459 Children's social competence and sociometric status: Further exploration of aggression, social withdrawal, and peer rejection

485 Developmental variables in relation to depressive symptoms in adolescent girls 


\section{CONTENTS}

Special Issue: Milestones in the Development of Resilience

\section{DANTE CiccheTti AND NORMAN GARMEZY \\ EMMY E. WERNER}

BYRON EGELAND, Elizabeth CARLSON, and L. Alan SROufe

RICHARD RENDE AND ROBERT PLOMIN

Ursula M. Staudinger, MICHAEL MARSISKe, AND PAUL B. BALTES

Michelle G. Carro, KATHRYN E. GRANT, IAN H. GotLIB, AND BRUCE E. COMPAS

MARIAN RADKE-YARROW AND EARNESTINE BROWN

MARILYN CONRAD AND CONSTANCE HAMMEN

JOHN E. RICHTERS AND PEDRo E. MARTINEZ

Dante Cicchetti, Fred A. ROGOSCH, MICHAEL LYNCH, AND KATHLEEN D. HoLT

Peter A. WyMAN, EMORY L. COWEN, WILLIAM C. WORK, AND JUDY H. KERLEY
497 Editorial. Prospects and promises in the study of resilience

503 Risk, resilience, and recovery: Perspectives from the Kauai Longitudinal Study

517 Resilience as process

529 Families at risk for psychopathology: Who becomes affected and why?

541 Resilience and levels of reserve capacity in later adulthood: Perspectives from life-span theory

567 Postpartum depression and child development: An investigation of mothers and fathers as sources of risk and resilience

581 Resilience and vulnerability in children of multiple-risk families

593 Protective and resource factors in high- and low-risk children: A comparison of children with unipolar, bipolar, medically ill, and normal mothers

609 Violent communities, family choices, and children's chances: An algorithm for improving the odds

629 Resilience in maltreated children: Processes leading to adaptive outcome

649 The role of children's future expectations in self-system functioning and adjustment to life stress: A prospective study of urban at-risk children 
SCOTT D. Gest, JENNIFER NEEMANN, JON J. HUBBARD, ANN S. MASTEN, AND AUKe TELLEGEN

MAGDa StOUTHAMER-LOEBER, ROLF LOEBER, DAVID P. FARRINGTON, QuANWU ZhaNG, WELMOET VAN KAMMEN, AND EUGENE MAGUIN

SUNIYA S. LUTHAR, CAROL H. DOERnBerger, AND EDWARD ZIGLER

Margaret Beale Spencer, STEVEN P. Cole, DAVIDO DUPREE, ALVIN GLyMPH, AND PHAEDRA PIERRE

Alfred L. Baldwin, Clara P. BaldWin, TIMOTHY KASSER, Melvin Zax, ARNOLD SAMEROFF, AND RONALD SEIFER

DAvid QuiNTON, ANDREW PICKLES, BARBARA MAUGHAN, AND MICHAEL RUTTER
663 Parenting quality, adversity, and conduct problems in adolescence: Testing process-oriented models of resilience

683 The double edge of protective and risk factors for delinquency: Interrelations and developmental patterns

703 Resilience is not a unidimensional construct: Insights from a prospective study of inner-city adolescents

719 Self-efficacy among urban African American early adolescents: Exploring issues of risk, vulnerability, and resilience

741 Contextual risk and resiliency during late adolescence

763 Partners, peers, and pathways: Assortative pairing and continuities in conduct disorder 